\title{
Laceyella tengchongensis sp. nov., a thermophile isolated from soil of a volcano
}

Correspondence
Wen-Jun Li
liact@hotmail.com

The genus Thermoactinomyces was first described by Tsilinsky (1899). Lacey \& Cross (1989) placed the genus Thermoactinomyces in the family Bacillaceae as the only thermoactinomycete genus (Stackebrandt \& Woese, 1981). The genus was later divided into four genera: Thermoactinomyces, Laceyella, Thermoflavimicrobium and Seinonella (Yoon et al., 2005). Subsequently, two new genera, Planifilum and Mechercharimyces, were described and a new family, Thermoactinomycetaceae, was proposed (Hatayama et al., 2005; Matsuo et al., 2006). At the time of writing, the genus Laceyella comprises only two species: Laceyella sacchari (basonym Thermoactinomyces sacchari Lacey 1971) and Laceyella putida (basonym Thermoactinomyces putidus Lacey and Cross 1989) (Lacey \& Vince, 1971; Lacey \&

The GenBank/EMBL/DDBJ accession number for the 16S rRNA gene sequence of strain YIM $10002^{\top}$ is FJ426598.

A scanning electron micrograph of growth of strain $\mathrm{YIM} 10002^{\top}$ and comparisons of polar lipids and fatty acids for the genus Laceyella are available as supplementary material with the online version of this paper.
Cross, 1989; Yoon et al., 2000, 2005). Members of the genus Laceyella are Gram-positive, aerobic, thermophilic, filamentous bacteria. Aerial and substrate mycelia are formed and sessile endospores may be produced on sporophores. The predominant menaquinone is MK-9, the major fatty acids are iso- $\mathrm{C}_{15: 0}$ and anteiso- $\mathrm{C}_{15: 0}$ and the DNA G $+\mathrm{C}$ content is $48-49 \mathrm{~mol} \%$ (Yoon et al., 2005).

Volcanoes and hot springs, for which Tengchong county is famous, are special habitats. As part of an investigation of the diversity of thermophilic micro-organisms in these environments, strain YIM $10002^{\mathrm{T}}$ was isolated from a soil sample collected from Big Empty Volcano in Tengchong county, Yunnan province, south-west China. In this study, $2 \mathrm{~g}$ soil sample was suspended in $18 \mathrm{ml}$ sterile water and mixed at $55{ }^{\circ} \mathrm{C}$ for $30 \mathrm{~min}$. Soil particles were allowed to sediment, the liquid phase was diluted to $1: 100$ and $100 \mu \mathrm{l}$ aliquots were spread onto the surface of isolation agar and incubated at $55{ }^{\circ} \mathrm{C}$ for a week. Strain YIM $10002^{\mathrm{T}}$ was isolated from International Streptomyces Project (ISP) medium 3 (Shirling \& Gottlieb, 1966). The isolate was 
maintained on ISP 3 agar slants at $4{ }^{\circ} \mathrm{C}$ and as suspensions of mycelium fragments in glycerol $(20 \%, \mathrm{v} / \mathrm{v})$ at $-80{ }^{\circ} \mathrm{C}$.

Biomass for chemical and molecular studies was obtained by cultivation in ISP 3 broth in shaken flasks (about 150 r.p.m.) at $55{ }^{\circ} \mathrm{C}$ for 1 week. Cultural characteristics were determined after 1-2 weeks by methods used by the ISP (Shirling \& Gottlieb, 1966). The colours of substrate and aerial mycelia and any soluble pigments produced were determined by comparison with chips from the ISCC-NBS colour charts (Kelly, 1964). Strain YIM $10002^{\mathrm{T}}$ grew well on ISP 3 agar, moderately well on Czapek's, ISP 2 and ISP 4 agar, weakly on ISP 5 agar and not at all on nutrient agar. The aerial and substrate mycelia were white to whiteyellow. No soluble pigment was produced. The morphological characteristics of strain YIM $10002^{\mathrm{T}}$ were observed by light microscopy (BH-2; Olympus) and scanning electron microscopy (JSM-5600LV; JEOL) after growth on ISP 3 agar at $55{ }^{\circ} \mathrm{C}$ for 14 days. The substrate and aerial mycelia of the isolate were well developed and formed endospores (Supplementary Fig. S1, available in IJSEM Online).

Growth of strain YIM $10002^{\mathrm{T}}$ was tested at 4, 10, 15, 20, 28, $37,40,45,55,65,70$ and $75{ }^{\circ} \mathrm{C}$ on ISP 3 agar. The $\mathrm{pH}$ range for growth was investigated at ISP 3 agar at $\mathrm{pH} 4.0-10.0$ (at intervals of $1 \mathrm{pH}$ unit) using the following buffer systems: $0.1 \mathrm{M}$ citric acid/0.1 M sodium citrate ( $\mathrm{pH} 4.0-5.0), 0.1 \mathrm{M}$ $\mathrm{KH}_{2} \mathrm{PO}_{4} / 0.1 \mathrm{M} \mathrm{NaOH}\left(\mathrm{pH} 6.0-8.0\right.$ ) and $0.1 \mathrm{M} \mathrm{NaHCO}_{3} /$
$0.1 \mathrm{M} \mathrm{Na}_{2} \mathrm{CO}_{3}$ (pH 9.0-10.0). The media and procedures used to determine physiological features and the carbon source utilization pattern were those described by Williams et al. (1989). Strain YIM $10002^{\mathrm{T}}$ grew well at $55{ }^{\circ} \mathrm{C}$, but not below $28{ }^{\circ} \mathrm{C}$ or above $70{ }^{\circ} \mathrm{C}$, showing that the strain was thermophilic, and at $\mathrm{pH}$ 6.0-8.0. The above morphological features of strain YIM $10002^{\mathrm{T}}$ are consistent with those of members of the genus Laceyella described by Yoon et al. (2005). Strain YIM $10002^{\mathrm{T}}$ could be distinguished easily from the two described Laceyella species by using a battery of phenotypic properties (Table 1).

Isomers of diaminopimelic acid and whole-cell sugars were analysed according to the procedures developed by Hasegawa et al. (1983). Polar lipids were extracted and examined by two-dimensional TLC and identified using procedures described by Minnikin et al. (1984). Menaquinones were extracted according to Minnikin et al. (1984) and separated by HPLC (Kroppenstedt, 1982). For fatty acid analysis, cells were collected after growth in tryptic soy broth (Difco) in shaken flasks (about 150 r.p.m.) at $55{ }^{\circ} \mathrm{C}$ for 2 days. Cellular fatty acid analysis was performed as described by Sasser (1990) using the Microbial Identification System (MIDI). Strain YIM $10002^{\mathrm{T}}$ contained meso-diaminopimelic acid as the cell-wall diamino acid and ribose, xylose and glucose as the major whole-cell sugars. The menaquinones were MK-9 $(87 \%)$ and MK-8 (13\%). The phospholipids comprised diphosphatidylglycerol, phosphatidylglycerol, phosphatidylethanolamine, phosphatidylinositol, phosphatidylinositol

Table 1. Differentiating characteristics of strain $\mathrm{YIM} 10002^{\top}$ and its closest phylogenetic neighbours

All data were obtained in this study. +, Positive; v, variable; - , negative.

\begin{tabular}{|c|c|c|c|}
\hline Characteristic & Strain YIM $10002^{\mathrm{T}}$ & L. sacchari DSM $43356^{\mathrm{T}}$ & L. putida DSM $44608^{\mathrm{T}}$ \\
\hline Melanin production & - & $\mathrm{V}$ & + \\
\hline Temperature range for growth $\left({ }^{\circ} \mathrm{C}\right)$ & $28-70$ & $35-65$ & $30-65$ \\
\hline \multicolumn{4}{|l|}{ Degradation of: } \\
\hline Hypoxanthine & + & - & - \\
\hline \multicolumn{4}{|l|}{ Utilization of: } \\
\hline D-Fructose & - & + & - \\
\hline Glycine & - & + & + \\
\hline Lactose & + & + & - \\
\hline L-Lysine & + & - & - \\
\hline D-Mannitol & + & + & - \\
\hline Phospholipids $\dagger$ & DPG, PE, PG, PI, PIM, PL & DPG, PE, PME, PI, PIM, PL & DPG, PE, PG, PI, PIM, PL \\
\hline Menaquinones & MK-9, MK-8 & MK-9, MK-8, MK-10 & MK-9, MK-8 \\
\hline
\end{tabular}

${ }^{\star}$ Ara, Arabinose; Glc, glucose; Rib, ribose; Xyl, xylose.

$\nmid$ DPG, Diphosphatidylglycerol; PE, phosphatidylethanolamine; PG, phosphatidylglycerol; PI, phosphatidylinositol; PIM, phosphatidylinositol mannosides; PME, phosphatidylmonomethylethanolamine; PL, unknown phospholipid. 
mannosides and some unknown phospholipids. Strain YIM $10002^{\mathrm{T}}$ had a cellular fatty acid profile that contained major amounts of branched fatty acids and minor amounts of straight-chain and unsaturated fatty acids: iso- $\mathrm{C}_{15: 0}$ $(57.63 \%)$, anteiso- $\mathrm{C}_{15: 0}(13.79 \%)$, iso- $\mathrm{C}_{16: 0}(8.88 \%)$, iso$\mathrm{C}_{14: 0}(7.11 \%)$, iso- $\mathrm{C}_{17: 0}(3.62 \%)$, anteiso- $\mathrm{C}_{17: 0}(1.83 \%)$, $\mathrm{C}_{16: 0}(1.61 \%)$, iso- $\mathrm{C}_{13: 0}(1.32 \%)$, summed feature 5 (iso$\mathrm{C}_{17: 1} \mathrm{I}$ and/or anteiso- $\left.\mathrm{C}_{17: 1} \mathrm{~B} ; 1.18 \%\right), \mathrm{C}_{14: 0}(1.16 \%), \mathrm{C}_{18: 1}$ cis $9(1.02 \%)$ and $\mathrm{C}_{17: 0}(0.85 \%)$ (Supplementary Table S1). On the whole, the chemotaxonomic properties for strain YIM $10002^{\mathrm{T}}$ were consistent with those of members of the genus Laceyella (Yoon et al., 2005), but the strain differed from $L$. sacchari DSM $43356^{\mathrm{T}}$ by having ribose as a whole-cell sugar (Table 1) and phosphatidylglycerol as a phospholipid (Supplementary Fig. S2). Genomic DNA was extracted and purified according to the method described by Marmur (1961) and, using the HPLC method (Mesbah et al., 1989), the DNA G $+\mathrm{C}$ content of strain YIM $10002^{\mathrm{T}}$ was $48.6 \mathrm{~mol} \%$.

Extraction of genomic DNA and PCR amplification and sequencing of the $16 \mathrm{~S}$ rRNA gene of strain YIM $10002^{\mathrm{T}}$ were performed as described by Li et al. (2007). A multiple alignment with sequences most closely related to the genus Laceyella and calculations of sequence similarity were performed using EzTaxon server 2.0 (Chun et al., 2007). Phylogenetic analyses were performed using three treemaking algorithms: neighbour joining (Saitou \& Nei, 1987), maximum likelihood (Felsenstein, 1981) and maximum parsimony (Fitch, 1971). A phylogenetic tree was constructed using the neighbour-joining method of Saitou \& Nei (1987) from $K_{\text {nuc }}$ values (Kimura, 1980) using MEGA version 4.0 (Tamura et al., 2007). The topology of the phylogenetic tree was evaluated by the bootstrap resampling method of Felsenstein (1985) with 1000 replicates. DNA-DNA relatedness between strain YIM $10002^{\mathrm{T}}$ and $L$. sacchari DSM $43356^{\mathrm{T}}$ and L. putida DSM $44608^{\mathrm{T}}$ was determined in triplicate according to the optical renaturation method (De Ley et al., 1970; Huß et al., 1983; Jahnke, 1992).

An almost-complete 16S rRNA gene sequence (1398 bp) of strain YIM $10002^{\mathrm{T}}$ was obtained. $16 \mathrm{~S}$ rRNA gene sequence similarities between strain YIM $10002^{\mathrm{T}}$ and L. sacchari KCTC $9790^{\mathrm{T}}$ and L. putida KCTC $3666^{\mathrm{T}}$ were 99.9 and
$98.0 \%$, respectively. Strain YIM $10002^{\mathrm{T}}$ showed $<95.2 \%$ sequence similarity with other members of the family Thermoactinomycetaceae. In the phylogenetic tree based on the neighbour-joining algorithm (Fig. 1), strain YIM $10002^{\mathrm{T}}$ formed a cluster with $L$. sacchari KCTC $9790^{\mathrm{T}}$ and L. putida KCTC $3666^{\mathrm{T}}$ that was supported with a high bootstrap value $(99 \%)$. The topologies of the maximumlikelihood and maximum-parsimony trees were similar to that of the neighbour-joining tree (data not shown). The results of $16 \mathrm{~S}$ rRNA gene sequence analysis clearly demonstrated that strain YIM $10002^{\mathrm{T}}$ was a member of the genus Laceyella. DNA-DNA relatedness between strain YIM $10002^{\mathrm{T}}$ and L. sacchari DSM $43356^{\mathrm{T}}$ and L. putida DSM $44608^{\mathrm{T}}$ was 34.0 and $39.0 \%$, respectively, values that are far below the $70 \%$ cut-off value recommended for the assignment of a strain to a novel genomic species (Wayne et al., 1987).

Strain YIM $10002^{\mathrm{T}}$ exhibited morphological characteristics that were typical of the genus Laceyella and the phylogenetic data clearly linked this strain to the genus Laceyella. However, comparison of the phenotypic characteristics of strain YIM $10002^{\mathrm{T}}$ and its closest phylogenetic neighbours revealed significant differences between them, including production of soluble pigment and melanin, degradation of hypoxanthine and starch, temperature range for growth and utilization of L-lysine and glycine. Hence, on the basis of phylogeny, DNA-DNA relatedness and chemotaxonomic and phenotypic characters, we consider that strain YIM $10002^{\mathrm{T}}$ represents a novel species, for which the name Laceyella tengchongensis sp. nov. is proposed.

\section{Description of Laceyella tengchongensis sp. nov.}

Laceyella tengchongensis (teng.chong.en'sis. N.L. fem. adj. tengchongensis pertaining to Tengchong county, Yunnan province, south-west China, where the type strain was collected).

Gram-positive, aerobic, thermophilic, filamentous actinomycete. Substrate and aerial mycelia are well developed and form endospores $(0.7-0.8 \mu \mathrm{m})$. Aerial and substrate mycelia are white to yellow-white. No soluble pigment is produced. Positive for gelatin liquefaction and milk peptonization and coagulation and negative for nitrate reduction and $\mathrm{H}_{2} \mathrm{~S}$ and

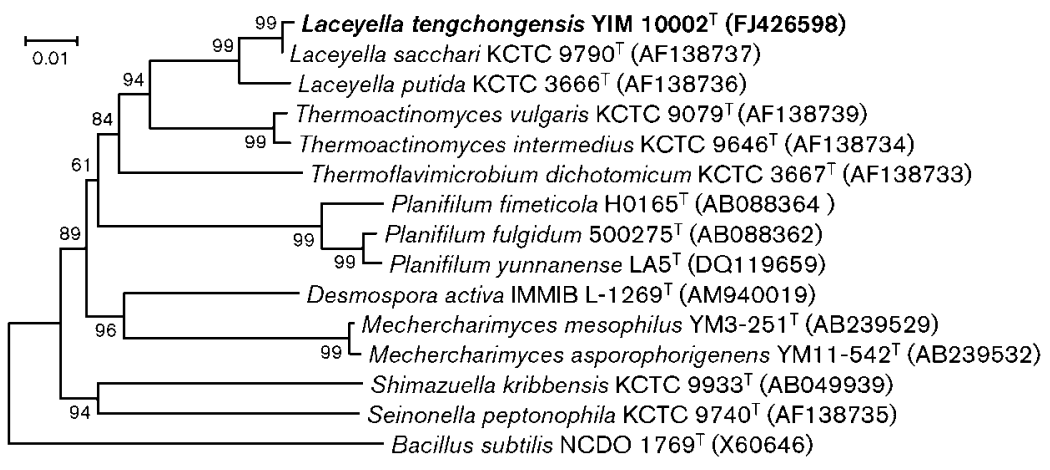
Fig. 1. Phylogenetic dendrogram based on 16S rRNA gene sequences, reconstructed from evolutionary distances with the neigh- bour-joining method, showing the position of strain YIM $10002^{\top}$ within the family Thermoactinomycetaceae. Bootstrap values (>50\%) based on 1000 replicates are shown at branch nodes. Bacillus subtilis NCDO $1769^{\top}$ was used as an outgroup. Bar, $1 \%$ sequence divergence.


melanin production. Casein, hypoxanthine, gelatin and Ltyrosine are degraded, but adenine, xanthine, starch and urea are not. L-Fucose, lactose, mannitol and L-rhamnose are utilized as carbon sources, but D-arabinose, D-fructose, D-galactose, maltose, D-mannose, raffinose, D-ribose and Dxylose are not. L-Arginine, L-asparagine, L-cysteine, L-lysine and L-threonine are used as nitrogen sources, but adenine, glycine, L-hydroxyproline, L-proline, L-serine, L-valine and xanthine are not. The cell wall contains meso-diaminopimelic acid as the diagnostic amino acid of peptidoglycan. The whole-cell sugars are ribose, xylose and glucose. The predominant menaquinone is MK-9. The polar lipids are diphosphatidylglycerol, phosphatidylglycerol, phosphatidylethanolamine, phosphatidylinositol, phosphatidylinositol mannosides and some unknown phospholipids. The major cellular fatty acids are iso- $\mathrm{C}_{15: 0}$ and anteiso- $\mathrm{C}_{15: 0}$. The DNA $\mathrm{G}+\mathrm{C}$ content of the type strain is $48.6 \mathrm{~mol} \%$.

The type strain is YIM $10002^{\mathrm{T}}\left(=\mathrm{DSM} 45262^{\mathrm{T}}=\right.$ CCTCC AA $208050^{\mathrm{T}}$ ), isolated from a soil sample collected from Big Empty Volcano in Tengchong county, Yunnan province, south-west China.

\section{Acknowledgements}

This research was supported by the National Basic Research Program of China (no. 2010CB833800) and Yunnan Provincial Science and Technology Department (nos 2009AC017 and 2009DA002).

\section{References}

Chun, J., Lee, J.-H., Jung, Y., Kim, M., Kim, S., Kim, B. K. \& Lim, Y. W. (2007). EzTaxon: a web-based tool for the identification of prokaryotes based on $16 \mathrm{~S}$ ribosomal RNA gene sequences. Int J Syst Evol Microbiol 57, 2259-2261.

De Ley, J., Cattoir, H. \& Reynaerts, A. (1970). The quantitative measurement of DNA hybridization from renaturation rates. Eur $J$ Biochem 12, 133-142.

Felsenstein, J. (1981). Evolutionary trees from DNA sequences: a maximum likelihood approach. J Mol Evol 17, 368-376.

Felsenstein, J. (1985). Confidence limits on phylogenies: an approach using the bootstrap. Evolution 39, 783-791.

Fitch, W. M. (1971). Towards defining the course of evolution: minimum change for a specific tree topology. Syst Zool 20, 406416.

Hasegawa, T., Takizawa, M. \& Tanida, S. (1983). A rapid analysis for chemical grouping of aerobic actinomycetes. J Gen Appl Microbiol 29, 319-322.

Hatayama, K., Shoun, H., Ueda, Y. \& Nakamura, A. (2005). Planifilum fimeticola gen. nov., sp. nov. and Planifilum fulgidum sp. nov., novel members of the family 'Thermoactinomycetaceae' isolated from compost. Int J Syst Evol Microbiol 55, 2101-2104.

Huß, V. A. R., Festl, H. \& Schleifer, K.-H. (1983). Studies on the spectrophotometric determination of DNA hybridization from renaturation rates. Syst Appl Microbiol 4, 184-192.

Jahnke, K. D. (1992). BASIC computer program for evaluation of spectroscopic DNA renaturation data from Gilford System 2600 spectrophotometer on a PC/XT/AT type personal computer. J Microbiol Methods 15, 61-73.
Kelly, K. L. (1964). Inter-Society Color Council - National Bureau of Standards Color Name Charts Illustrated with Centroid Colors. Washington, DC: US Government Printing Office.

Kimura, M. (1980). A simple method for estimating evolutionary rates of base substitutions through comparative studies of nucleotide sequences. J Mol Evol 16, 111-120.

Kroppenstedt, R. M. (1982). Separation of bacterial menaquinones by HPLC using reverse phase (RP18) and a silver loaded ion exchanger as stationary phases. J Liq Chromatogr 5, 2359-2367.

Lacey, J. \& Cross, T. (1989). Genus Thermoactinomyces Tsilinsky $1899,501^{\mathrm{AL}}$. In Bergey's Manual of Systematic Bacteriology, vol. 4, pp. 2574-2585. Edited by S. T. Williams, M. E. Sharpe \& J. G. Holt. Baltimore: Williams \& Wilkins.

Lacey, J. \& Vince, D. A. (1971). Endospore formation and germination in a new Thermoactinomyces species. In Spore Research, pp. 181-187. Edited by A. N. Barker, G. W. Gould \& J. A. Wolf. London: Academic Press.

Li, W. J., Xu, P., Schumann, P., Zhang, Y. Q., Pukall, R., Xu, L. H., Stackebrandt, E. \& Jiang, C. L. (2007). Georgenia ruanii sp. nov., a novel actinobacterium isolated from forest soil in Yunnan (China) and emended description of the genus Georgenia. Int J Syst Evol Microbiol 57, 1424-1428.

Marmur, J. (1961). A procedure for the isolation of deoxyribonucleic acid from microorganisms. J Mol Biol 3, 208-218.

Matsuo, Y., Katsuta, A., Matsuda, S., Shizuri, Y., Yokota, A. \& Kasai, H. (2006). Mechercharimyces mesophilus gen. nov., sp. nov. and Mechercharimyces asporophorigenens sp. nov., antitumour substanceproducing marine bacteria, and description of Thermoactinomycetaceae fam. nov. Int J Syst Evol Microbiol 56, 2837-2842.

Mesbah, M., Premachandran, U. \& Whitman, W. B. (1989). Precise measurement of the $\mathrm{G}+\mathrm{C}$ content of deoxyribonucleic acid by highperformance liquid chromatography. Int J Syst Bacteriol 39, 159-167.

Minnikin, D. E., O’Donnell, A. G., Goodfellow, M., Alderson, G., Athalye, M., Schaal, A. \& Parlett, J. H. (1984). An integrated procedure for the extraction of bacterial isoprenoid quinones and polar lipids. J Microbiol Methods 2, 233-241.

Saitou, N. \& Nei, M. (1987). The neighbor-joining method: a new method for reconstructing phylogenetic trees. Mol Biol Evol 4, 406425.

Sasser, M. (1990). Identification of bacteria by gas chromatography of cellular fatty acids. USFCC Newsl 20, 16.

Shirling, E. B. \& Gottlieb, D. (1966). Methods for characterization of Streptomyces species. Int J Syst Bacteriol 16, 313-340.

Stackebrandt, E. \& Woese, C. R. (1981). Towards a phylogeny of the actinomycetes and related organisms. Curr Microbiol 5, 197-202.

Tamura, K., Dudley, J., Nei, M. \& Kumar, S. (2007). MEGA4: molecular evolutionary genetics analysis (MEGA) software version 4.0. Mol Biol Evol 24, 1596-1599.

Tsilinsky, P. (1899). On the thermophilic moulds. Ann Inst Pasteur 13, 500-505 (in French).

Wayne, L. G., Brenner, D. J., Colwell, R. R., Grimont, P. A. D., Kandler, O., Krichevsky, M. I., Moore, L. H., Moore, W. E. C., Murray, R. G. E. \& other authors (1987). International Committee on Systematic Bacteriology. Report of the ad hoc committee on reconciliation of approaches to bacterial systematics. Int J Syst Bacteriol 37, 463464.

Williams, S. T., Goodfellow, M. \& Alderson, G. (1989). Genus Streptomyces Waksman and Henrici 1943, 339 $9^{\mathrm{AL}}$. In Bergey's Manual of Systematic Bacteriology, vol. 4, pp. 2463-2468. Edited by S. T. Williams, M. E. Sharpe \& J. G. Holt. Baltimore: Williams \& Wilkins. 
Yoon, J.-H., Shin, Y. K. \& Park, Y.-H. (2000). DNA-DNA relatedness among Thermoactinomyces species: Thermoactinomyces candidus as a synonym of Thermoactinomyces vulgaris and Thermoactinomyces thalpophilus as a synonym of Thermoactinomyces sacchari. Int J Syst Evol Microbiol 50, 1905-1908.
Yoon, J.-H., Kim, I.-G., Shin, Y.-K. \& Park, Y.-H. (2005). Proposal of the genus Thermoactinomyces sensu stricto and three new genera, Laceyella, Thermoflavimicrobium and Seinonella, on the basis of phenotypic, phylogenetic and chemotaxonomic analyses. Int J Syst Evol Microbiol 55, 395-400. 